\title{
Dose-dependency of theophylline clearance and protein binding
}

\author{
J A FlEETHAM, C E BIRD, K NAKATSU, R D WIGLE, AND P W MUNT
}

From the Departments of Medicine and Pharmacology, Queen's University, Kingston, Ontario, Canada

ABSTRACT Dose-dependency in theophylline pharmacokinetics and protein binding characteristics was examined in 10 healthy male volunteers. Theophylline disposition was determined after an intravenous infusion of both $1 \mathrm{mg} / \mathrm{kg}$ and $6 \mathrm{mg} / \mathrm{kg}$ aminophylline in a randomised crossover study. There was considerable intrasubject variability in theophylline clearance but no significant dose-dependency. Theophylline protein binding was assessed by equilibrium dialysis at varying theophylline concentrations. The percentage of free non-protein bound theophylline was significantly increased at high theophylline concentrations. This increase in free theophylline would lead to a non-linear increase in the risk of toxicity with increasing drug concentration.

Theophylline clearance has been assumed to follow first-order kinetics on the basis of close visual correspondence to logarithmic decay. ${ }^{1}$ This premise has, however, been questioned because of alinearity of the relationship between theophylline dose and serum theophylline concentration; fractional increases of a large theophylline dose produce greater fractional increments in serum theophylline than do fractional increments of a small dose. ${ }^{2}{ }^{3}$ Other evidence against theophylline clearance behaving according to first-order kinetics include failure of serum theophylline concentrations to decline exponentially after a dose of the drug $^{4-6}$ and differences in theophylline clearance depending on steady state values of serum theophylline. ${ }^{7}$ Several other drugs such as phenytoin ${ }^{8}$ and salicylates ${ }^{9}$ follow dose-dependent or zeroorder kinetics, and if the same phenomena exist in theophylline kinetics this would be clinically relevant in a drug with a relatively narrow therapeutic range, the dosage of which often has to be varied for optimal therapy.

Theophylline has been shown to have variable protein-binding characteristics dependent upon subject age, ${ }^{10}$ disease, ${ }^{11}$ and $\mathrm{pH} .{ }^{12}$ These studies have usually been performed at one theophylline concentration and possible dose-dependence of

Presented in part at the 74th Annual Meeting of the American Thoracic Society, Las Vegas, Nevada, USA, 1979.

Address for reprint requests: Dr JA Fleetham, F2-Respiratory Laboratory Health Sciences Centre, 700 William A venue, Winnipeg, Manitoba, R3E 0Z3, Canada. theophylline protein binding has not been investigated.

We have carried out a study to examine theophylline pharmacokinetics and protein binding in a group of normal subjects looking for any evidence of dose-dependency in these two variables.

\section{Methods}

Ten normal male volunteers, aged $22-38$ years and weighing 58 to $101 \mathrm{~kg}$, were investigated. All gave informed consent to a protocol approved by a university ethics committee. One, RW, was a smoker and none was on any medication or had any evidence of hepatic dysfunction as detected by history and routine liver function tests. All were healthy and none varied their dietary habits during the study.

\section{PHARMACOKINETIC STUDIES}

The subjects received on two separate days intravenous infusions of aminophylline (Glaxo: theophylline ethylenediamine, anhydrous theophylline equivalent $78 \%$ ). 'The drug was administered in 6 $50 \mathrm{ml}$ of normal saline at a constant rate over $20 \overparen{D}$ minutes. The infusions contained either $1 \mathrm{mg} / \mathrm{kg}$ ? body weight or $6 \mathrm{mg} / \mathrm{kg}$ body weight of aminophylline and were given four days apart in a randomised crossover fashion. The absence of detectable concentrations of the drug in the serum before the study was confirmed by a sample obtained before the drug was administered. After each 
infusion $5 \mathrm{ml}$ blood samples were obtained every half hour for the first hour and every hour for the subsequent eight hours. Sera were separated and stored at $-20^{\circ} \mathrm{C}$ until analysis. Theophylline concentration was measured by high pressure liquid chromatography. ${ }^{13}$ This assay is specific for theophylline, is not affected by xanthines or other drugs, and has a sensitivity of better than $0 \cdot 4 \mu \mathrm{g} / \mathrm{ml}$.

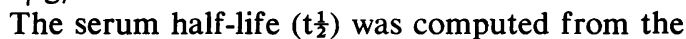
slope of the equilibrium phase (that period when the drug concentration in serum and tissues is in equilibrium) of the theophylline elimination curve. This slope was determined by linear regression. Theophylline serum clearance was defined as the volume of blood cleared of drug per unit body weight per unit time, and was obtained by dividing the dose infused by the area under the curve extrapolated to infinity. ${ }^{14}$ The apparent volume of distribution was calculated by dividing the serum clearance by the elimination rate constant $(\beta)$. $\left(\beta=0.693 / \mathrm{t} \frac{1}{2}\right.$ where 0.693 is the natural $\log$ of 2$)$. Statistical analysis of the group pharmacokinetic data was performed using a Student's paired $t$ test.

\section{PROTEIN BINDING STUDIES}

Serum was obtained from the subjects before the pharmacokinetic studies. Theophylline protein binding was determined at $37^{\circ} \mathrm{C}$ and $\mathrm{pH} 7 \cdot 4$ by an equilibrium dialysis technique previously described to assess testosterone protein binding. ${ }^{15}$ Serum $(0.5$ $\mathrm{ml}$ ) was placed in dialysis tubing and then incubated for 18 hours in phosphate buffered saline containing ${ }^{14} \mathrm{C}$ labelled theophylline (specific activity $38 \mathrm{mCi} / \mathrm{mmole}$, New England Nuclear Company). Total theophylline concentrations in the buffer solution were adjusted with unlabelled theophylline and were $1 \cdot 5,15$, and $45 \mu \mathrm{g} / \mathrm{ml}$. The sera and incubation media were then counted separately in a scintillation counter for 10 minutes. Subtraction of the total counts in the buffer from those in the serum allowed calculation of the relative amounts of free and bound theophylline in the serum. Statistical analysis of the protein binding data was performed using analysis of variance and a two-sided Tukey's procedure. ${ }^{16}$

\section{Results}

The results of the pharmacokinetics data are displayed in the table. Infusion of $6 \mathrm{mg} / \mathrm{kg}$ body weight aminophylline produced a mean theophylline concentration range from $14 \cdot 1 \mu \mathrm{g} / \mathrm{ml}$ to $4 \cdot 3$ $\mu \mathrm{g} / \mathrm{ml}$ and of $1 \mathrm{mg} / \mathrm{kg}$ body weight aminophylline a mean theophylline concentration range of 2.9 $\mu \mathrm{g} / \mathrm{ml}$ to $0.7 \mu \mathrm{g} / \mathrm{ml}$ during the nine-hour study. Serum half-life and apparent volume of distribution tended to increase and body clearance decrease with the higher theophylline dose (fig 1). None of these changes attained statistical significance.

Total protein concentration ranged from 6.8$7.4 \mathrm{~g} / 100 \mathrm{ml}$ and albumin concentration ranged from $4 \cdot 2-4.7 \mathrm{~g} / 100 \mathrm{ml}$ in our subjects. The percentage of theophylline protein bound at varying theophylline concentration is shown in fig 2 .

Table Pharmacokinetic data

\begin{tabular}{|c|c|c|c|c|c|}
\hline Subject & $\begin{array}{l}\text { Dosage of aminophvlline/ } \\
\text { body weight }\end{array}$ & $\begin{array}{l}\text { Range of serum } \\
\text { theophylline after } \\
\text { infusion }(\mu \mathrm{g} / \mathrm{ml})\end{array}$ & Serum half-life $(h)$ & $\begin{array}{l}\text { Apparent volume of } \\
\text { distribution }(l / k g)\end{array}$ & $\begin{array}{l}\text { Body } \\
\text { clearance } \\
\text { ml/kg/h) }\end{array}$ \\
\hline RW & $\begin{array}{l}1 \mathrm{mg} / \mathrm{kg} \\
6 \mathrm{mg} / \mathrm{kg}\end{array}$ & $\begin{array}{r}2 \cdot 8-0.6 \\
14 \cdot 8-3.4\end{array}$ & $\begin{array}{l}4 \cdot 7 \\
5 \cdot 4\end{array}$ & $\begin{array}{l}0.427 \\
0.433\end{array}$ & $\begin{array}{l}62.9 \\
55 \cdot 5\end{array}$ \\
\hline JF & $\begin{array}{l}1 \mathrm{mg} / \mathrm{kg} \\
6 \mathrm{mg} / \mathrm{kg}\end{array}$ & $\begin{array}{r}2 \cdot 2-0 \cdot 8 \\
14 \cdot 2-6 \cdot 5\end{array}$ & $\begin{array}{l}6.9 \\
9.0\end{array}$ & $\begin{array}{l}0.454 \\
0.439\end{array}$ & $\begin{array}{l}45 \cdot 5 \\
33 \cdot 8\end{array}$ \\
\hline $\mathbf{K N}$ & $\begin{array}{l}1 \mathrm{mg} / \mathrm{kg} \\
6 \mathrm{mg} / \mathrm{kg}\end{array}$ & $\begin{array}{r}2 \cdot 3-0 \cdot 8 \\
12 \cdot 8-3 \cdot 8\end{array}$ & $\begin{array}{r}70 \cdot 5 \\
8 \cdot 1\end{array}$ & $\begin{array}{l}0.459 \\
0.588 \\
0.622\end{array}$ & $\begin{array}{l}33 \cdot 8 \\
38 \cdot 8 \\
53 \cdot 2\end{array}$ \\
\hline $\mathbf{P M}$ & $1 \mathrm{mg} / \mathrm{kg}$ & $\begin{array}{r}3 \cdot 2-1 \cdot 0 \\
12 \cdot 2-5 \cdot 2\end{array}$ & $\begin{array}{r}9 \cdot 5 \\
11 \cdot 5\end{array}$ & $\begin{array}{l}0.484 \\
0.543\end{array}$ & $\begin{array}{l}35 \cdot 3 \\
32 \cdot 7\end{array}$ \\
\hline DB & $\begin{array}{l}1 \mathrm{mg} / \mathrm{kg} \\
6 \mathrm{mg} / \mathrm{kg}\end{array}$ & $\begin{array}{r}3 \cdot 6-0 \cdot 4 \\
12 \cdot 2-4 \cdot 1\end{array}$ & $\begin{array}{l}4 \cdot 0 \\
7 \cdot 3\end{array}$ & $\begin{array}{l}0.579 \\
0.533\end{array}$ & $\begin{array}{r}100 \cdot 3 \\
50 \cdot 5\end{array}$ \\
\hline PG & $\begin{array}{l}1 \mathrm{mg} / \mathrm{kg} \\
6 \mathrm{mg} / \mathrm{kg}\end{array}$ & $\begin{array}{r}3 \cdot 0-0 \cdot 4 \\
18 \cdot 0-3 \cdot 7\end{array}$ & $\begin{array}{l}3 \cdot 5 \\
5 \cdot 8\end{array}$ & $\begin{array}{l}0.493 \\
0.499\end{array}$ & $\begin{array}{l}97 \cdot 6 \\
59 \cdot 6\end{array}$ \\
\hline $\mathbf{K H}$ & $\begin{array}{l}1 \mathrm{mg} / \mathrm{kg} \\
6 \mathrm{mg} / \mathrm{kg}\end{array}$ & $\begin{array}{r}2.8-0.9 \\
13.9-4.6\end{array}$ & $\begin{array}{r}10 \cdot 2 \\
8 \cdot 0\end{array}$ & $\begin{array}{l}0.526 \\
0.493\end{array}$ & $\begin{array}{l}35 \cdot 7 \\
42 \cdot 7\end{array}$ \\
\hline $\mathbf{H H}$ & $\begin{array}{l}1 \mathrm{mg} / \mathrm{kg} \\
6 \mathrm{mg} / \mathrm{kg}\end{array}$ & $\begin{array}{r}2 \cdot 8-0 \cdot 4 \\
15 \cdot 5-4 \cdot 1\end{array}$ & $\begin{array}{l}5 \cdot 3 \\
6 \cdot 4\end{array}$ & $\begin{array}{l}0.462 \\
0.477\end{array}$ & $\begin{array}{l}60 \cdot 4 \\
51 \cdot 6\end{array}$ \\
\hline PE & $\begin{array}{l}1 \mathrm{mg} / \mathrm{kg} \\
6 \mathrm{mg} / \mathrm{kg}\end{array}$ & $\begin{array}{r}2 \cdot 8-1 \cdot 0 \\
14 \cdot 2-4 \cdot 4\end{array}$ & $\begin{array}{l}8 \cdot 4 \\
6 \cdot 5\end{array}$ & $\begin{array}{l}0.406 \\
0.448\end{array}$ & $\begin{array}{l}33 \cdot 4 \\
47 \cdot 7\end{array}$ \\
\hline CP & $\begin{array}{l}1 \mathrm{mg} / \mathrm{kg} \\
6 \mathrm{mg} / \mathrm{kg}\end{array}$ & $\begin{array}{r}3 \cdot 1-0 \cdot 8 \\
12 \cdot 7-3 \cdot 4\end{array}$ & $\begin{array}{l}6 \cdot 3 \\
5 \cdot 9\end{array}$ & $\begin{array}{l}0.470 \\
0 \cdot 528\end{array}$ & $\begin{array}{l}51 \cdot 7 \\
62 \cdot 0\end{array}$ \\
\hline $\begin{array}{l}\text { Mean } \\
\text { SEM }\end{array}$ & $\begin{array}{l}1 \mathrm{mg} / \mathrm{kg} \\
6 \mathrm{mg} / \mathrm{kg}\end{array}$ & $\begin{array}{r}2 \cdot 9 \pm 0 \cdot 1-0 \cdot 7 \pm 0 \cdot 1 \\
14 \cdot 1 \pm 0 \cdot 6-4 \cdot 3 \pm 0 \cdot 3\end{array}$ & $\begin{array}{l}6 \cdot 93 \pm 0.82 \\
7 \cdot 39 \pm 0.58\end{array}$ & $\begin{array}{l}0.488 \pm 0.018 \\
0.501 \pm 0.018\end{array}$ & $\begin{array}{l}56 \cdot 2 \pm 7 \cdot 8 \\
48 \cdot 9 \pm 3 \cdot 2\end{array}$ \\
\hline
\end{tabular}




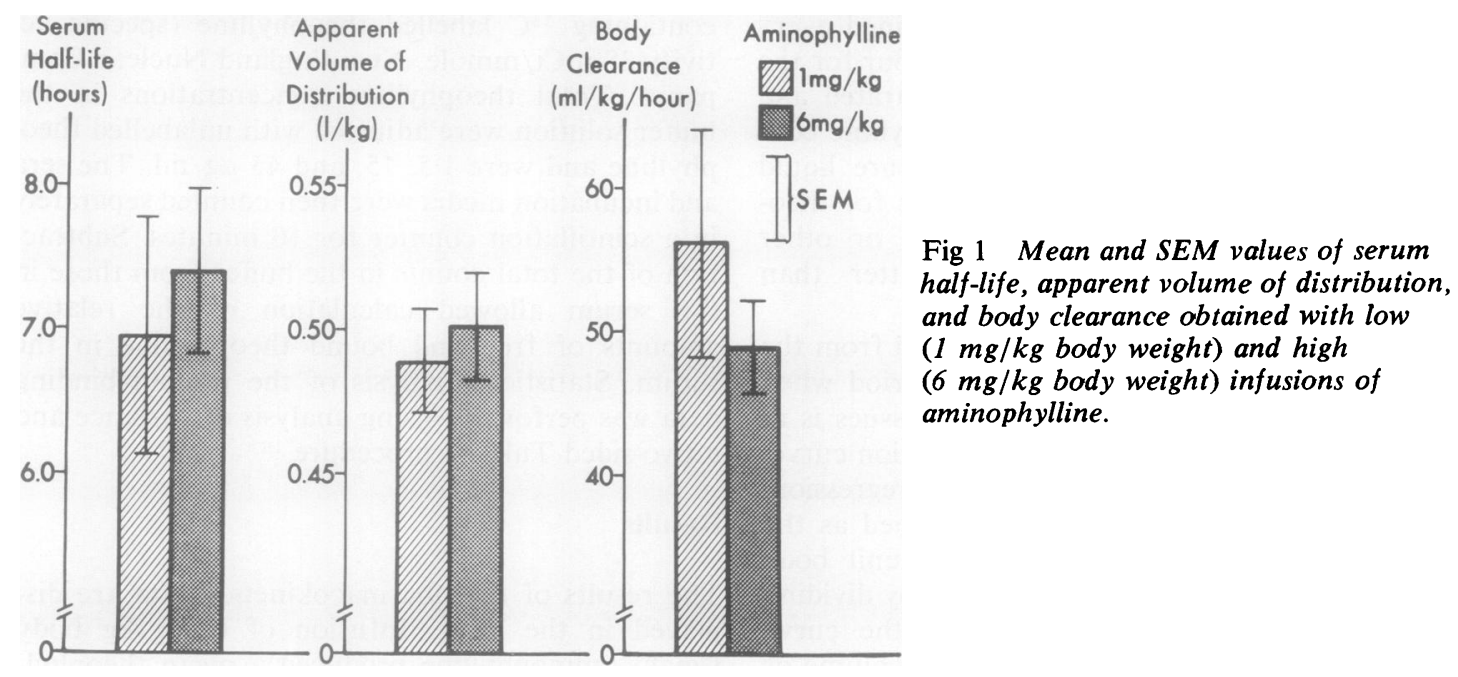

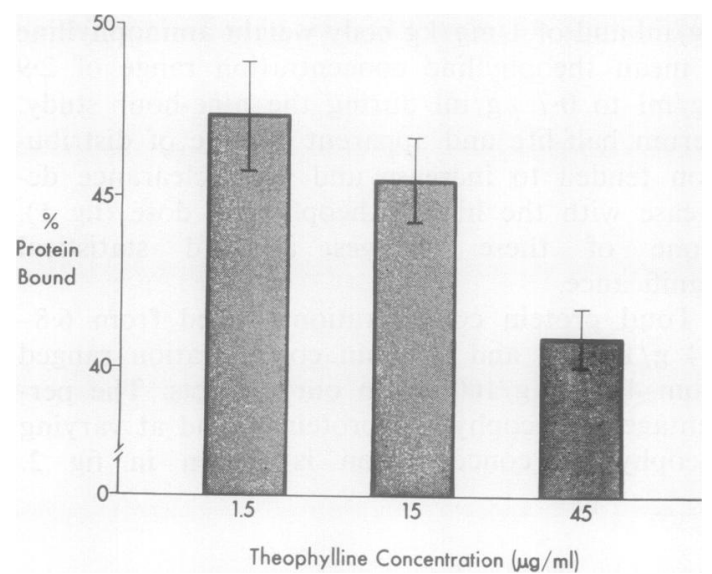

Fig 2 Mean and SEM values for the percentage of theophylline protein bound at varying serum theophylline concentrations.

There is a trend for less theophylline to be protein bound with increasing theophylline concentration. This is significant between $1.5 \mu \mathrm{g} / \mathrm{ml}$ and $45 \mu \mathrm{g} / \mathrm{ml}$ $(\mathrm{p}<0.01)$ and between $15 \mu \mathrm{g} / \mathrm{ml}$ and $45 \mu \mathrm{g} / \mathrm{ml}$ $(\mathrm{p}<0.05)$.

\section{Discussion}

The majority of drugs are eliminated as a firstorder process. The characteristic of a first-order process is that during the equilibrium phase the half-life of the drug is the same regardless of which point on the serum concentration curve is chosen as the starting point for the measurement. The elimination of some important drugs such as phenytoin ${ }^{8}$ and salicylates ${ }^{9}$ do not follow first-order kinetics. In these drugs clearance is not a constant value, but changes as concentrations in the body fall during elimination. This pattern of elimination is known as dose-dependent or zero-order kinetics. Theophylline elimination has been assumed by Mitenko and Ogilvie $^{1}$ to follow first-order kinetics on the basis of close visual correspondence to logarithmic decay. The possibility of zero-order kinetics was initially raised by Jenne et $a l^{2}$ when they noticed occasional disproportionate changes in serum theophylline concentrations as a result of changes in oral theophylline dosage in adults. Similar observations were made by Lucey et $a l^{17}$ in premature infants and Ginchansky and Wein berge ${ }^{3}$ in children, when trying to individualise oral theophylline therapy. On at least three separate occasions serum theophylline concentrations have been serially followed in patients accidentally overdosed with theophylline and in each, the theophylline degradation curve was not described by a single exponential function. ${ }^{5-7}$

Our data do not support the presence of dosedependent kinetics in the range of theophylline concentrations examined. As such they conflict with the data of Weinberger et $a l^{7}$ who demonstrated differing theophylline clearances at two different infusion dosages in steady state theophylline studies in asthmatic children. This discrepancy may be explained by the fact that Weinberger et $a l^{7}$ obtained much higher serum theophylline concentrations $(15 \cdot 7-30.8 \mu \mathrm{g} / \mathrm{ml})$ than we did with their high dose infusion. These concentrations are in general above the commonly accepted therapeutic range for theophylline of 10 to $20 \mu \mathrm{g} / \mathrm{ml}$ 
In addition, Weinberger et $a l^{7}$ studied children whereas we studied adults, and it has been shown ${ }^{8}$ that other drugs such as salicylates demonstrate dose-dependent kinetics at lower drug concentrations in children than in adults.

Two of our subjects (DB and PG) had marked decreases in theophylline clearance with the higher dose theophylline infusion. It is possible that dose-dependent kinetics exist and the theophylline concentration at which the transition from first-order to dose-dependent kinetics occurs varies between individuals. However a more likely explanation is that these decreases are caused by the known random intrasubject variability of theophylline clearance. ${ }^{18}$ So although previous studies have suggested that theophylline elimination is dose-dependent, our study suggests that this does not occur in the usual therapeutic range. Further, dose-dependent theophylline kinetics may be of less clinical relevance than the large random variation of theophylline elimination in heath and disease. ${ }^{19}$ Safe and effective theophylline therapy requires periodic estimations of serum theophylline concentrations.

Our data demonstrate dose-dependence of the percentage of theophylline protein bound. At a theophylline concentration of $15 \mu \mathrm{g} / \mathrm{ml}$ we found an average of $45.6 \%$ theophylline protein bound, comparable to the mean $49.4 \%$ theophylline protein bound recently reported by Vallner et al ${ }^{12}$ using a similar equilibrium dialysis technique. The amount of theophylline protein bound has been shown to be decreased in hepatic cirrhosis, ${ }^{11}$ acidosis, ${ }^{12}$ and in neonates, ${ }^{10}$ and might be predicted to vary in a variety of other clinical situations such as renal dysfunction and pregnancy. ${ }^{20}$ Because protein bound drug is in general pharmacologically inactive, conditions that affect protein binding might alter the therapeutic and toxic drug effects as well as drug disposition. ${ }^{21}$ However, Gillette ${ }^{22}$ has suggested that changes in protein binding are only relevant to pharmacological activity when the drug is more than $90 \%$ protein bound. In addition, the changes in protein binding we demonstrate are small within the range of serum theophylline usually encountered in clinical settings. However theophylline has a narrow therapeutic margin and an increase in free theophylline may contribute to the development of toxic symptoms in the high therapeutic range.

The effects of plasma protein on drug distribution and elimination is controversial. ${ }^{23}$ In drugs with high hepatic extraction ratios (the ratio of hepatic clearance divided by hepatic blood flow) such as propranolol, binding to plasma protein serves as a transport vehicle to enhance delivery of drug to the elimination site. Whereas, in drugs like theophylline with a low hepatic extraction ratio $^{19}$ the fraction of drug that is bound to plasma protein may be considered as a reservoir that slows elimination and lengthens half-life. Thus the increased free theophylline present at high serum theophylline concentration could not account for the dose-dependency of theophylline clearance which has previously been proposed at comparable theophylline concentrations. ${ }^{7}$ It should however be emphasised that many factors other than theophylline protein binding, affect theophylline disposition. ${ }^{24}$

This work was supported by the Ontario Respiratory Disease Foundation. JAF is a Fellow of the Medical Research Council of Canada.

\section{References}

1 Mitenko PA, Ogilvie RI. Pharmacokinetics of intravenous theophylline. Clin Pharmacol Ther 1973; 14:509-13.

2 Jenne JW, Wyze E, Rood BS, MacDonald FM. Pharmacokinetics of theophylline: application to adjustment of the clinical dose of aminophylline. Clin Pharmacol Ther 1972; 13:349-60.

3 Ginchansky E, Weinberger MM. Relationship of theophylline clearance to oral dosage in children with chronic asthma. J Pediatr 1977; 91: $655-60$.

4 Nicholson DP, Chick TW. A re-evaluation of parenteral aminophylline. Am Rev Respir Dis 1973; 108:241-7.

5 Kadlec GJ, Jarboe CH, Pollard SJ, Sublett JL. Acute theophylline intoxication biphasic first order elimination kinetics in a child. Ann Allergy 1978; 41:337-9.

6 Fleetham JA, Ginsburg J, Nakatsu N, Wigle RD, Munt PW. Resin hemoperfusion as a treatment for theophylline-induced seizures. Chest 1979; 75: 741-2.

7 Weinberger M, Ginchansky E. Dose-dependent kinetics of theophylline disposition in asthmatic children. J Pediatr 1977; 91:820-4.

8 Gugler R, Manion CV, Azarnoff DL. Phenytoin pharmacokinetics and bioavailability. Clin Pharmacol Ther 1976; 19:135-42.

9 Levy G, Tsuchiya T. Salicylate accumulation kinetics in man. $N$ Engl $J$ Med 1972; 287:430-2.

10 Aranda JB, Sitar DS, Parsons WD, Loughnan PE, Neims AH. Pharmacokinetics aspects of theophylline in premature newborns. $N$ Engl J Med 1976; 295:413-6.

11 Piafsky KM, Sitar DS, Rango RE, Ogilvie RI. Theophylline disposition in patients with hepatic cirrhosis. N Engl J Med 1977; 296:1495-7.

12 Vallner JJ, Speir WA, Kolbeck RC, Harrison GN, Bransome ED. Effect of $\mathrm{pH}$ on the binding 
of theophylline to serum proteins. Am Rev Respir Dis 1979; 120:83-6.

13 Nakatsu K, Owen JA, Scully K. Reliable fifteen minute assay for theophylline. Clin Biochem 1978; 11:148-9.

14 Hendeles L, Weinberger M, Bighley L. Disposition of theophylline after a single intravenous infusion of aminophylline. Am Rev Respir Dis 1978; 118:97-103.

15 Clark AF, Calandra RS, Bird CE. Binding of testosterone and $5 \alpha$-dihydrotestosterone to plasma proteins in humans. Clin Biochem 1971; 4:89-103.

16 Tukey JW. The problem of multiple comparisons. JW Tukey, Princeton University, Princeton, NJ, 1953.

17 Lucey JF, Shannon DC, Soyka LF. Apnea of prematurity. Report of Seventy-First Ross Conference on Pediatric Research. Columbus, Ohio:
Ross Laboratories, 1977:46.

18 Walson PD, Strunk RC, Taussig LM. Intrapatient variability in theophylline kinetics. $J$ Pediatr 1977; 91:321-4.

19 Ogilvie RI. Clinical pharmacokinetics of theophylline. Clin Pharmacokinet 1978; 3:267-93.

20 Koch-Weser J, Sellers EM. Binding of drugs to serum albumin. $N$ Engl J Med 1976; 294:311-6.

21 Vallner JJ. Binding of drugs by albumin and plasma protein. J Pharm Sci 1977; 66:447-65.

22 Gillette JR. Overview of drug-protein binding. Ann NY Acad Sci 1973; 226:6-17.

23 Wagner JG. A modern view of pharmacokinetics. J Pharmacokinet Biopharm 1973; 11:363-401.

24 DuSouich P, McLean AJ, Lalka D, Erill S, Gibaldi M. Pulmonary disease and drug kinetics. Clin Pharmacokinet 1978; 3:257-66. 